\title{
Zpráva o jednom osudu
}

\author{
Libor Vodička
}

Michaela Malčíková. Na divadlo neumřu. Otakar Roubinek. Praha: Brkola, 2014. 141 s.

O dramaturgovi se většinou moc neví a už vůbec nepíše, není-li $\mathrm{k}$ tomu zvláštního důvodu. Proč také, když - kromě výjimek potvrzujících pravidlo - na jeviště před diváky nevystupuje a na konci představení se neklaní. Jeho úkolem z podstaty je být téměř neviděn $\mathrm{v}$ pozadí, promýšlet, formulovat, programovat a každodenní dění $\mathrm{v}$ divadle sledovat svým pozorným okem. Žít s divadlem, dýchat s tvưrci, ale také dalšími pracovníky divadla (třeba i s tak často podceňovanými techniky, samozřejmě s produkcí a administrativou, zkrátka rozumět jim, jejich práci, podmínkám a potřebám), vést vnímavý dialog s diváky (v jejich pestrosti a mnohosti), přitom si uchovávat od všeho zdravý odstup, je-li to vůbec možné, kritický a sebekritický, otevřený všemu, nejvíce pak pochybnostem, které však v jisté fázi nesmí už dát najevo. Pokud lze hovořit o dramaturgii jako o umění, pak je to především umění říci správná slova ve správný čas, anebo pomlčet - také ve správný čas. Protože týmová souhra divadelní práce je velice křehký útvar, zvláště pak v situacích, kdy sólisté mezi sebou soutěží, a jak známo, generál musí svést bitvu právě a jen s tím vojskem, které osudem dostal. Tím „generálem“ je v současném divadle pochopitelně režisér, dramaturg má úkol být mu empatickým rezonérem a oponentem, neustále „číst mapu“, jak trefně říkal Peter Scherhaufer, definovat „souřadnice“ dané chvíle. Zkrátka být partnerem a obětavým pomocníkem, bez nároku na „já“, které se dočká svého veřejného uznání.

Takovou výjimkou, nedávno spatřivší světlo světa, je knižní vydání magisterské diplomové práce Michaely Malčíkové, absolventky brněnské teatrologie, nyní zaměstnané na pozici archivářky v Městském divadle Brno. Když se před několika lety pustila do své práce o Otakaru Roubínkovi, tušili jsme, že velkým problémem bude heuristika, která určuje budoucí výsledek. Malčíková to vskutku neměla vůbec snadné, až na některé výjimky, jako bylo např. někdejší Divadlo pracujících v Gottwaldově, kde Roubínek působil ovšem nejdéle (1960-1970), se musela spolehnout mnohdy jen na dobové recenze, v lepším případě na ročenky divadel, v nichž Roubínek působil, jen tu a tam na podstatnější archivní prameny spíše interního charakteru a samozřejmě vzpomínky či ojedinělé rozhovory. V úvodu je třeba konstatovat, že s těmito podmínkami se autorka vypořádala výborně, ostatně vedena byla zkušenou vedoucí práce Evou Stehlíkovou.

Kniha je logicky členěna podle etap Roubínkova osobního a tvưrčího vývoje. Po krátké biografické kapitole následuje pojednání zaměřené na jeho školní léta na DAMU, kde v letech 1954-1958 absolvoval studium herectví pod vedením Boženy Půlpánové, Miloše Nedbala a Františka Vnoučka. Všímá si potřebných souvislostí (např. s kým a jakým zpo̊sobem se setkal v tvưrčím i osobním životě, kdo měl vliv 
na jeho další směřování apod.), přičemž jádrem této kapitoly je Roubínkovo účinkování v DISKu. Následuje část věnovaná jeho prvnímu profesionálnímu angažmá v Beskydském divadle, kde v letech 1958-1960 působil jako sólista činohry. I když Beskydské divadlo mělo v jisté době (1948-1956) poměrně vysokou uměleckou úroveň, za Roubínka to už neplatilo, naopak v té době tato oblastní scéna zápasila více než kdy před tím s elementárními problémy. Umělecký život fatálně ovlivňovaly nuzné materiální a technické podmínky, snad ještě více než politický a ideologický tlak na repertoár či vyznění inscenací, a začínající herec tu měl poznat spíše tu horší stránku divadelního provozu, včetně odlivu diváků. Však také z této etapy pochází trefná Roubínkova citace v úvodu statě: „Ujištuji vás, že přes všechna nepohodlí a přes opravdu zásadní těžkosti a nedostatky lze žít u oblastního divadla nesmírně spokojeně a pohodlně, v tom nejhorším slova smyslu.“ (19) Tři roky po Roubínkově odchodu bylo divadlo v rámci reorganizace a restrikce vlastně z ekonomických důvodů rozhodnutím zřizovatele zrušeno...

To už však Roubínek působil $\mathrm{v}$ hereckém souboru "gottwaldovského" divadla, kde se záhy začal etablovat také jako lektor dramaturgie a později jako tvưrčí a osobitý dramaturg. Ne že by měl zrovna na růžích ustláno, jeho pozice nebyla automatická a je pozoruhodné sledovat, jak to na oblasti chodí, když se do repertoáru prosazují tituly, které snesou vyšší nároky, mezi Skyllou kritiky a Charybdou divácké přízně. Zajímavé je také vysledovat, kterak se jeho herecká psychosomatická letora a bytostně intelektuální esprit sešly teprve s dramatikou, která vyžaduje civilnější polohy hereckého projevu a jemnější valéry (např. v intonaci) pro vyznění stylizace, oproštěné zejména od výraznější exprese a „silných“ gest, od prožívání a hereckého přetělesňování. Vyplývá to jednoznačně z dobových kritických reflexí, které Roubínkovy herecké postavy oceňují častěji až v souvislostech s absurdní a epickou dramatikou. (Např. „Romeo O. Roubínka dost nepřesvědčuje, že láska k Julii se mu stala smyslem života. [...] je to láska rozmělněná a zcivilněná, nikoli onen prudký, očistný a životodárný cit renesančního člověka.“ (22) - „Roubínek, gottwaldovský Plzák [...] zvolil stereotypní bodrou intonaci vět, krátké pauzy mezi větami vyplňuje nepř́ijemně se vnucujícím smíchem. [...] intonace [...] je základním prvkem vytvářejícím postavu.“ (33)). Pozorný čtenář tu spolu s autorkou, která se však ke škodě věci nevyjádří přímo a v širší zobecňující úvaze, vystopuje spojnici k Vyskočilovu „nedivadelnímu“ projevu založenému na osobním ručení, na mravní apelaci skrze téma, postoj a vlastní osobnost.

Kdy jindy, než po srpnu 1968 musela Roubínkova osobnost i letora roztáhnout svá kř́ídla k nejvyššímu letu, po němž ovšem přišel zákonitý pád. Roubínkova aktivita v Klubu angažovaných nestraníků nemohla uniknout režimním sluhům nastupující normalizace a fatálně ovlivnila jeho profesní možnosti v následujícím dvacetiletí, které žel bylo fakticky také závěrečnou etapou jeho tvưrčí práce i životní pouti.

Po vynuceně dobrovolném odchodu ze stále gottwaldovského Divadla pracujících (1970) čekala Roubínka nejprve zaměstnání v panelárně a na pile, přičemž ani tehdy se zcela nevzdal tvưrčí práce (např. úprava soudniček Františka Němce pro Obvodní kulturní a vzdělávací středisko v Brně - Králově Poli). Následovalo dlouhé období nejistoty existenční, částečných úvazků a přechodných spoluprací, prací na zapřenou 
a polo-zaměstnaneckých vazeb. Nejprve krátká epizoda v Divadle za branou, kam nastoupil jako vedoucí propagace a náboru, souběžně spolupracoval s ústeckým Činoherním studiem jako lektor dramaturgie, posléze také jako produkční, scénárista, dramaturg a jako herec s pražskou Lyrou pragensis, jako produkční Parku kultury a oddechu Julia Fučíka, Divadla hudby v Praze aj. Vystopovat tyto nejasné a krátké, někdy třeba několik měsíců trvající etapy Roubínkova osudu a jeho tvůrčí práce muselo dát autorce velké úsilí. Právě tato část knihy podle mne patří k významným příspěvkům k dějinám divadla za tzv. normalizace. Sám pisatel těchto řádků, také již do jisté míry pamětník, dobře ví, jak nesnadné je vysvětlit dnešním mladým lidem strategie jednání dobových aktérů, zvláště pak tzv. šedé zóny, přizpůsobující se podmínkám a současně atakující hranice povoleného a možného... Jako pars pro toto tohoto fenoménu lze pak nahlížet na Roubínkovu spolupráci s Divadlem Na zábradlí v 80. letech. S divadlem, které na jedné straně patřilo k ostře sledované výkladní skříni socialistické měštanské kultury normalizační doby, na straně druhé k pozoruhodnému ostrůvku „pozitivní deviace“, jenž se pokoušel v rámci možností vytvořit paralelní strukturu v rámci oficiální kultury. Ač by tato etapa zasloužila hlubší a samostatné studie, jako kapitola monografie patří jednoznačně $\mathrm{k}$ vrcholům její knihy.

Netřeba se na tomto místě dále rozepisovat o Roubínkově aktivní účasti na listopadové stávce divadelníků a studentů v roce 1989, na jeho mnoha dalších podniknu- tích a tvůrčích spolupracích, o jeho opusu magnum - monografii František Ferdinand Šamberk (Melantrich 1985) a o dalších souvislostech jeho tvůrčí i životní pouti, kterou tvrdě přervala nemoc a předčasná smrt. Laskavý čtenář necht si přečte sám. Zdržím se pouze souvislosti, která je spojena se současností více než bychom si snad i připustili a jež je pro mne důkazem, že na počátku naší novodobé etapy demokratického vývoje českého divadla jsme bolestně ztratili dva velké dramaturgy, jejichž vnímavost, poučenost, osobní pokora a schopnost žít a dýchat s divadlem a jeho diváky byly nebývalé. Mám na mysli právě Otakara Roubínka a Václava Königsmarka. Bude-li jednou někdo hledat argumenty pro to, v čem se chybovalo v 90 . letech a s porevolučním optimismem zahodilo, povrchně spláchlo, nechalo ladem nebo zapomnělo, nalezne to především v nemnoha vyjádřeních, rozhovorech či textech těchto dvou dramaturgů s velkou vizí a malým pochopením svými spoluběžci. Autorka monografie si v této věci naordinovala možná trochu zbytečnou zdrženlivost a ve snaze po věcnosti a faktech nám někdy může chybět zobecnění, tedy její názor.

Závěrem pouze připomeňme, že součástí knihy je soupis článků, recenzí a studií OR, anket, odpovědí na ankety, rozhovorů a další bibliografie; soupis zaměstnání, inscenací, rolí atd., na nichž se podílel, jakož i obrazová př́loha. Je dobré vědět a je dobré číst.

DOI: $10.5817 / T Y 2016-1-15$ 